\title{
ANALISIS WACANA DALAM NOVEL ASSALAMUALAIKUM \\ CALON IMAM KARYA MADANI \\ Harinawat,MA ${ }^{1}$, Awaludin Arifin ${ }^{2} \&$ Maria Ulfa $^{3}$ \\ $1 \& 2$ Dosen program Studi Ilmu Komunikasi Universitas Malikussaleh \\ Email: harinawati@unimal.ac.id \\ ${ }^{3}$ Alumnus Ilmu Komunikasi Universitas Malikussaleh
}

\begin{abstract}
ABSTRAK
Novel Assalamualaikum Calon Imam menceritakan tentang kehidupan seorang tokoh bernama Nafisya Kaila Akbar yang ingin menemukan calon imam terbaiknya disaat dia takut menjatuhkan hati pada seseorang karena tidak ingin terluka sama seperti orangtuanya. Pendekatan penelitian yang digunakan adalah deskriptif kualitatif dengan metode analisis wacana model Teun A. Van Dijk yang berdasarkan struktur teks, kognisi sosial, dan konteks sosial. Tujuan penelitian ini untuk mendeskripsikan isi atau pesan yang terkandung dalam novel Assalamualaikum Calon Imam karya Madani. Hasil penelitian ini menunjukkan bahwa pesan moral dalam novel Assalamualaikum Calon Imam karya Madani adalah moral dalam hubungan manusia dengan Tuhan yang berupa ketakwaan, dan bersyukur. Moral dalam hubungan manusia dengan manusia lain yang berupa berupa nilai moral nasihat orang tua kepada anak, kasih sayang orang tua dan anak, nasihat antar teman, peduli sesama, dan beramal soleh. Moral dalam hubungan manusia dengan diri sendiri yang berupa pesan kesabaran, bertanggung jawab, keteguhan pendirian, dan kebijaksanaan. Dari segi kognisi sosialnya cukup menggambarkan kereligiusan pengarangnya. Sementara itu dari konteks sosial, novel ini merupakan pesan atau amanat pengarang bagi pembacanya, bahwa sebuah pernikahan yang berakhir dengan perceraian tidak hanya berdampak bagi orang dewasa saja, tetapi juga bagi anak Kata Kunci: Analisis Wacana, Novel, dan Agama
\end{abstract}

\section{Latar Belakang Masalah}

Karya sastra merupakan hasil kreativitas pengarang dalam menyampaikan ekspresi, ide, atau pikiran pengarang terhadap segala macam seni kehidupan manusia. Karya sastra bersifat imajinatif, estetik, dan menyenangkan pembaca. Ini menjadikan karya sastra sebagai media komunikasi persuasif yang baik karena di dalam karya sastra seorang penulis dapat mengungkapkan kejadian atau peristiwa secara kronologi dan sarat akan amanat. Karya sastra yang diciptakan penulis tidak hanya sekedar mengandalkan bakat dan kemahiran berekspresi, tetapi lebih dari itu, seorang penulis yang melahirkan karyanya memiliki visi, aspirasi, itikad baik dan perjuangan sehingga sastra yang dihasilkan memiliki nilai yang tinggi. Setiap pengarang yang menciptakan karya sastra, pasti mengandung nilai tertentu yang akan disampaikan kepada pembaca melalui tulisannya, misalnya nilai moral.

Dari banyaknya karya sastra sekarang ini, novel menjadi salah satunya. Novel merupakan karangan prosa yang dilihat dari panjangnya cerita, tertulis dalam bentuk 
naratif dan mengandung rangkaian kisah kehidupan. Novel lebih lengkap jika dibandingkan dengan cerpen (cerita pendek), umumnya novel memiliki alur yang rumit, banyak terdapat konflik-konflik dan cerita lebih panjang, tokoh yang terdapat dalam novel juga lebih banyak. Di dalam novel sangat jarang kita temukan gambar pada umumnya novel hanya berisi tulisan yang tebal yang bisa mencapai ratusan halaman atau lebih.

Sebagai sebuah media komunikasi, novel mempunyai fungsi layaknya fungsi komunikasi pada umumnya, yaitu menyiarkan informasi (to inform), mendidik (to educate), serta menghibur (to entertain). Beberapa ahli juga menambahkan fungsi dari media ini, seperti fungsi mempengaruhi (to influence), fungsi membimbing (to guide) dan juga fungsi mengkritik (to criticise). Novel memiliki kaitan erat dengan komunikasi yang dianggap sebagai suatu tulisan yang memberikan banyak informasi, pesan atau amanat yang membangun kepada pembaca dan terkadang dapat mengubah pola pikir seseorang. Sebagaimana pengertian komunikasi yang merupakan proses penyampaian pesan kepada komunikan melalui sebuah media yang diharapkan dapat mengubah tingkah laku. Maka apabila dilihat dari sudut pandang karya sastra, sumber adalah pengarang, komunikan adalah pembaca, media adalah novel, dan pesan merupakan isi di dalam novel.

Novel menjadi media komunikasi yang masih ampuh dalam menyampaikan pesan-pesan kepada masyarakat. Dengan menggunakan gaya bahasa yang menarik dan mudah dipahami membuat pembaca ingin mengetahui jalan cerita lebih lanjut dan membuat pembaca lebih mendalami pesan yang terdapat dalam novel. Hadirnya novel ditengah-tengah masyarakat seiring dengan kebutuhan manusia yang ingin memahami masalah yang ada melalui sebuah karya tulis.

Novel tidak hanya menjadi suatu bacaan yang menghibur, tetapi juga dapat menjadi teman mengobrol untuk menghilangkan rasa jenuh bagi seorang pembaca Menyukai cerita di dalam novel yang yang terkadang mengandung pelajaran dan pengajaran tentang konsep tingkah laku dan pola kehidupan masyarakat yang pada dasarnya setiap manusia ingin bergaul dan berusaha menyesuaikan diri dengan keadaan sekitarnya. Penyampaian pesan dalam novel dapat dilakukan oleh pengarang melalui aktivitas tokoh ataupun penutur langsung pengarang. Dalam penuturan langsung, pengarang memberikan penjelasan tentang hal yang baik ataupun hal yang tidak baik secara langsung. Demikian juga pesan yang terdapat dalam novel Assalamualaikum 
Calon Imam yang dapat memberikan manfaat bagi pembaca. Dalam novel ini, terdapat banyak ajaran dan amanat yang ditampilkan. Pesan moral dalam hubungan manusia dengan manusia, misalnya nilai kasih sayang orang tua dengan anak ataupun persoalan hidup antara hubungan manusia dengan Tuhan.

Novel Assalamualaikum Calon Imam merupakan karya dari seorang penulis muda bernama Madani. Novel ini sudah memikat lebih dari tiga juta pembaca di Wattpad, salah satu situs dan aplikasi populer untuk membaca dan menerbitkan cerita secara online. Pada November 2017, novel Assalamualaikum Calon Imam dirilis dalam bentuk cetak oleh penerbit Coconut Books. Kehadiran novel ini memang tampak berbeda karena memilih segmen yang lebih sempit ketimbang novel senada kompetitornya, yakni remaja muslimah. Penyajian jalan cerita yang penuh kejutan, menghentak-hentakkan, dan sulit ditebak menjadikan novel Assalamualaikum Calon Imam semakin menarik.

Penulis memilih novel ini sebagai bahan penelitian karena cerita ini banyak menampilkan persoalan hidup dan kehidupan yang menarik, serta terdapat banyak pesan atau amanat yang sangat bermanfaat bagi pembaca. Novel Assalamualaikum Calon Imam terkenal dengan kisah tentang perjuangan seorang remaja muslimah bernama Nafisya Kaila Akbar untuk menemukan calon imam terbaiknya. Dia takut tidak akan diakui sebagai umat-Nya dan tidak akan diakui sebagai hamba-Nya jika tidak mengikuti sunnah Rasulnya. Namun di sisi lain, Nafisya masih takut menjatuhkan hatinya pada seorang adam. Dia takut sama terluka dengan umminya. Bukan hal biasa mendengar perceraian orang tuanya ketika Nafisya menginjak umur lima tahun membuat Nafisya membenci sosok ayah, terlebih membuatnya tak percaya pada apa yang namanya laki-laki. Dalam novel Assalamualaikum Calon Imam, Ima tidak hanya membicarakan pesan tentang ajaran moral, tetapi juga persoalan bagaimana sebuah perceraian berdampak terhadap perkembangan seorang anak.

\section{Rumusan Masalah}

Adapun yang menjadi rumusan masalah dalam penelitian ini adalah bagaimana isi atau pesan yang terkandung dalam novel Assalamualaikum Calon Imam karya Madani?

\section{Landasan Teori}

\section{Analisis Wacana}


Analisis wacana berasal dari dua kata yaitu analisis dan wacana. Analisis adalah aktivitas yang terdiri dari serangkaian kegiatan seperti aktivitas mengurai, membedakan, dan memilah sesuatu untuk dikelompokkan berdasarkan kriteria tertentu kemudian dicari kaitannya dan ditafsirkan maknanya, Wirad (Makinuddin). Sedangkan wacana merupakan komunikasi kebahasaan yang dianggap sebagai sebuah pertukaran antara pembaca dan pendengar, sebagai sebuah aktivitas pribadi di mana bentuknya ditentukan oleh tujuan sosialnya, Hawtan, (Badara, 2012:16).

Wacana dapat dibedakan menjadi 2, yaitu wacana lisan dan wacana tulis. Wacana lisan ditemukan dalam percakapan, pidato, lelucon, sementara wacana tulis terutama pada media yang menggunakan bahasa tulis. Berikut adalah ciri-ciri wacana lisan (Hayon, 2017:42), yaitu:

1. Wacana lisan memiliki daya simak yang tinggal sehingga percakapan tidak akan terputus.

2. Wacana lisan sangat sulit diulang.

3. Wacana lisan dapat diperkuat dengan bahasa nonverbal untuk memperjelas makna yang dimaksud.

4. Wacana menyatukan partisipan dalam satu situasi dan konteks yang sama.

5. Wacana lisan biasanya lebih pendek dibandingkan dengan wacana tulisan.

6. Wacana tulisan menggunakan kebiasaan dan kemampuan yang sudah diketahui bersama (common ground), yang telah disepakati sesama kelompok.

7. Wacana lisan langsung melibatkan partisipan.

\section{Gambar 1:}

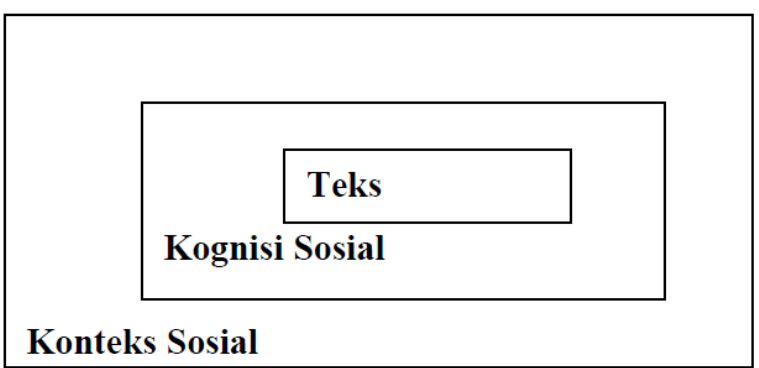

Menurut pemahaman yang dibuat Van Dijk (Eriyanto, 2007:227), ia melihat bahwa teks terdiri dari tiga struktur atau tingkatan yang masing-masing bagian saling mendukung. Struktur pertama yaitu struktur makro yang merupakan makna umum dari suatu teks yang dapat diamati atau tema yang tercantum dalam suatu tulisan atau berita. Struktur kedua yaitu superstruktur yang merupakan kerangka suatu teks yang melihat 
bagaimana bagian-bagian teks tersusun ke dalam berita atau tulisan secara baik dan benar. Struktur terakhir adalah struktur mikro, adalah makna wacana yang dapat diamati dari bagian terkecil dari suatu teks yakni kata, kalimat, proposisi, anak kalimat, parafrase dan gambar.

\section{Metode Penelitian}

Pendekatan yang digunakan dalam penelitian ini adalah pendekatan deskriptif kualitatif dengan menggunakan metode analisis wacana. Menurut Moleong (2011:4) pendekatan deskriptif kualitatif adalah penelitian yang bermaksud untuk memahami fenomena tentang apa yang dialami oleh subjek penelitian, misalnya perilaku, persepsi, motivasi, tindakan, dan lain-lain, secara holistik dan dengan cara deskripsi dalam bentuk kata-kata dan bahasa, pada suatu konteks khusus yang alamiah dan dengan memanfaatkan berbagai metode alamiah.

\section{HASIL PENELITIAN DAN PEMBAHASAN}

\section{Deskripsi Tentang Objek Penelitian}

Madani adalah nama pena dari Ima Madaniah, lahir di Bandung 24 Desember 1998. Madani memiliki hobi menulis kisah-kisah bergenre islam, selain itu perempuan yang baru menyelesaikan sekolah menengah ini tertarik pada bidang-bidang medis. Sama halnya dengan cita-citanya yang ingin menjadi Ibnu Sina abad ini.

Novel Assalamuaikum Calon Imam adalah projek pertama yang Madani tulis. Baginya menulis seperti ikut membuka jendela dunia. Menjadi sesuatu yang membanggakan dapat menciptakan jejak dalam kehidupan dan menabur hikmah lewat tulisan. Dalam penulisan Assalamualaikum Calon Imam, Ima Madani, menjadikan sosok guru Kimia di SMK Negeri 2 Cimahi, tempat dia sekolah, sebagai karakter yang galak dalam buku karangannya „Assalamualaikum Calon Imam“e. Buku tersebut menceritakan tentang kisah seorang anak laki-laki yang jahat terhadap ayahnya, namun setelah mendapat hidayah, anak laki-laki itu berbalik menjadi anak penurut.

Novel yang Ima selesaikan hanya dalam waktu satu tahun dengan ketebalan 414 ini menunjukkan kemampuan menulisnya yang tidak diragukan lagi. Perempuan berdarah Sunda itu, kini bahkan sedangkan menyiapkan buku kedua sebagai jawaban dari edisi pertama dengan judul „Waalaikumussalam Pelengkap Imam ${ }^{c e}$

\section{Gambar 4.1}

Cover Novel Assalamualaikum Calon Imam (2018) 


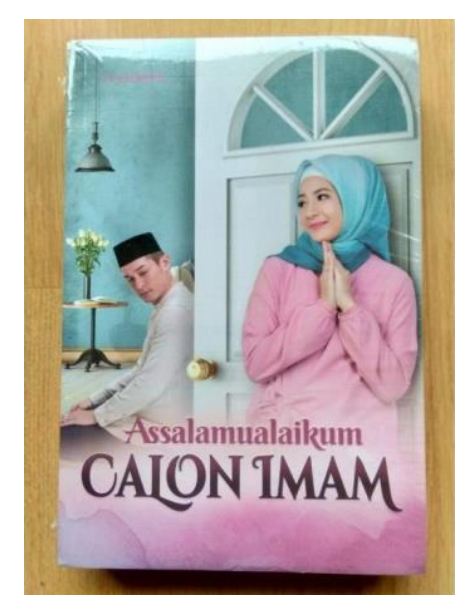

\section{Tokoh dan Penokohan}

Di dalam sebuah pembicaraan cerita fiksi, sering dipergunakan istilah-istilah seperti tokoh dan penokohan, karakter dan karakterisasi secara bergantian dengan menunjuk pengertian yang hampir sama. Istilah tokoh menunjuk pada orangnya, pelaku cerita. Tokoh cerita adalah orang-orang yang ditampilkan dalam suatu karya naratitf, atau drama, yang ditafsirkan oleh pembaca memiliki kualitas moral dan kecenderungan tertentu seperti yang dalam ucapan dan apa yang dilakukan dalam tindakan. Baldic (Nurgiantoro, 2017:247) menjelaskan tokoh adalah orang yang menjadi pelaku dalam cerita fiksi atau drama, sedang penokohan (characterization) adalah penghadiran tokoh dalam cerita fiksi baik dengan secara langsung atau tidak langsung dan mengundang pembaca untuk menafsirkan kualitas diri lewat kata dan tindakan.

Berdasarkan hal tersebut juga dapat diketahui bahwa diantara seorang tokoh dengan kualitas pribadinya berkaitan erat dalam penerimaan pembaca. Dalam hal ini, khusus dari pandangan teori persepsi, pembaca lah yang memberi arti dilakukan berdasarkan kata-kata (verbal) dan tingkah laku lain(nonverbal). Perbedaan antara tokoh yang satu dengan yang lain ditentukan oleh kualitas pribadi daripada yang terlihat secara fisik.

\section{Tabel 1}

\section{Tokoh dan Penokohan}

\begin{tabular}{|l|l|}
\hline $\begin{array}{l}\text { Tokoh paling sering muncul dalam } \\
\text { novel Assalamualaikum Calon } \\
\text { Imam karya Madani (2018) Tokoh }\end{array}$ & Karakter/Watak \\
\hline Nafisya Kaila Akbar & $\begin{array}{l}\text { Adalah tokoh utama dalam novel. Seorang } \\
\text { muslimah yang trauma akan pernikahan } \\
\text { karena perceraian orang tuanya saat masih }\end{array}$ \\
\hline
\end{tabular}




\begin{tabular}{|l|l|}
\hline & $\begin{array}{l}\text { kecil. Baik. Panikan. Pemaksa. Membenci } \\
\text { sosok Abi. Tidak bisa jatuh cinta. }\end{array}$ \\
\hline Alif Syaibani Alexis & $\begin{array}{l}\text { Adalah tokoh utama pria. Seorang dokter } \\
\text { bedah dan juga dosen di Fakultas } \\
\text { kedokteran. Alif digambarkan sebagai sosok } \\
\text { yang dingin, baik, dan tegas. Tokoh yang } \\
\text { menjadi suaminya Nafisya. }\end{array}$ \\
\hline Aisyah & $\begin{array}{l}\text { Adalah Ummi Nafisya. Sosok yang baik dan } \\
\text { seorang yang penyayang, sabar, dan ikhlas. }\end{array}$ \\
\hline Husain Akbar & $\begin{array}{l}\text { Adalah Abi Nafisya yang sangat menyayangi } \\
\text { keluarganya, terutama Nafisya. }\end{array}$ \\
\hline Salsya Sabila Akbar & $\begin{array}{l}\text { Adalah kakak dari Nafisya. Seorang dokter } \\
\text { di rumah sakit yang sama dengan Alif juga } \\
\text { seorang kakak yang penyayang. }\end{array}$ \\
\hline Jidan Ramdani & $\begin{array}{l}\text { Adalah tetangga Nafisya yang menjadi } \\
\text { teman teman kecil Nafisya. Lelaki soleh } \\
\text { yang Nafisya panggil makhluk mars dan } \\
\text { menjadi suaminya Salsya. }\end{array}$ \\
\hline
\end{tabular}

Setiap novel memiliki keunikan masing-masing dalam menyajikan cerita. Hal itu bergantung pada pengarang, bagaimana ia bisa menciptakan novel yang dapat menarik perhatian pembaca. Setiap bacaan yang dapat menjadi inspirasi dan pelajaran bagi banyak orang. Novel memiliki sifat yang tidak membosankan dan dapat menghilangkan rasa jenuh, juga dapat menghilangkan stress seseorang saat membacanya. Tidak dapat dipungkiri juga banyak novel yang memberi pelajaran hidup.

Novel Assalamualaikum Calon Imam karya Madani (2018) adalah kisah perjalanan hidup Nafisya Kaila Akbar yang memberikan banyak pelajaran bagi pembaca, menunjukkan ketakwaan melalui pesan-pesan yang terdapat dapat dalam novel. Seperti yang terdapat di dalam hasil penelitian pada tabel 4.3, wacana 2 yang berbunyi :

"Hidup itu pilihan, kan? Ya, pilihan, tanpa bisa memilih apa yang telah Allah pilihkan. Tapi percayalah, yang Allah adalah bagian paling indah." (Madani, 2018: 43)

Dan salah satu wacana 11 tabel 4.12, yang berbunyi :

"Kita salat berjamaah Magrib. Panggilan Allah lebih penting dari apapun." (Madani, 2018: 351)

Bersyukur menunjukkan terima kasih kita kepada sang pencipta. Setiap yang Allah berikan meski sekecil apapun itu. Pesan moral bersyukur seperti yang terdapat dalam hasil penelitian pada tabel 4.14, kutipan 1, yaitu : 
"Aku terbangun dengan perasaan takut. Kubuka mata perlahan, semuanya masih sama. Kuucap syukur ketika wajah Ummi masih bisa kulihat. Ternyata Allah masih memberikan waktu padaku untuk mengingat wajah bidadariku ini. ..." (Madani, 2018:

Menggambarkan kesabaran dengan belajar bersabar dari hal-hal yang kecil, salah satunya seperti yang terdapat dalam hasil penelitian pada tabel 4.2, kutipan 3, yaitu :

“... Indonesia memang tidak terlepas dari macet. Bagiku ini salah satu metode melatih kesabaran. Toh kalau kita tidak sabar, tetap akan macet, bukan?” (Madani, 2018: 16)

Tanggung jawab tidak terbatas hanya pada pekerjaan, diri sendiri, dan keluarga saja tetapi meliputi seluruh aspek kehidupan. Bertanggung jawab artinya kita memiliki kesadaran diri terhadap semua tingkah laku dan perbuatan yang sengaja ataupun tidak. Pesan moral bertanggung jawab salah satunya seperti yang terdapat dalam hasil penelitian pada tabel 4.11, kutipan 1, yaitu :

"Dan karena saya suami kamu, Abi kamu udah tititpin kamu ke saya. Apa yang harus saya bilang nanti kalau ngejaga kamu aja gak bisa?” (Madani, 2018: 315)

Kebijaksanaan tentang bagaimana menggunakan pengalaman dan pengetahuan dalam menghadapi permasalahan kehidupan. Pada hasil penelitian 4.10, kutipan 2, menunjukkan salah satu pesan moral kebijaksanaan, yang berbunyi :

"Dan karena saya suami kamu, Abi kamu udah tititpin kamu ke saya. Apa yang harus saya bilang nanti kalau ngejaga kamu aja gak bisa?" (Madani, 2018: 315).

Banyak sekali pelajaran dan pesan moral yang dapat diambil dari novel ini. Nasihat dari orang tua yang menunjukkan pesan moral hubungan manusia dan manusia, seperti yang terdapat di dalam tabel 4.14, wacana 13, yaitu :

"Dulu kamu paling benci perceraian. Sekarang apa? Sya, Ibnu Majah meriwayatkan: Setiap wanita yang meminta suaminya menceraikannya tanpa alasan maka wanita tersebut tak akan menghirup aroma surga.” (Madani, 2018: 398)

Yakinlah dalam diri kita bahwa kita bisa melewati masa sulit dalam hidup ini, dan dapat menggapai kebahagiaan yang kita inginkan. Berbagi dengan orang terdekat dan melangkah maju, terus tabah dan sabar dengan cobaan dan masalah yang kita hadapi, salah satunya seperti yang terdapat di dalam tabel 4.5, kutipan1, yaitu :

"Ketika kamu merasa bangkit maka bersujudlah. Turn to Allah before you return to Allah... itu rumus jitu untuk mrnjalani hidup.” (Madani, 2018: 102) 
Dari segi kognisi sosialnya pengarang memberi judul novelnya dengan yang kalimat yang bernuansa romantis dan penuh harap dalam kalimat "Assalamualaikum Calon Imam". Dengan pemilihan judul ini pembaca akan langsung dihadapkan pada sebuah pandangan tentang kisah romantis islami sebuah pernikahan. Pesan moral yang mengandung tiga kategori dapat pengarang gambarkan dalam novel Assalamualaikum Calon Imam yaitu penyampaian pesan yang bersumber dari nilai-nilai religi, moral serta adat-istiadat yang berlaku.

Konteks Sosial dalam hal ini adalah menjawab pernyataan mengenai bagaimana wacana yang berkembang di masyarakat mengenai pernikahan yang berakhir dengan perceraian. Penulis ingin menyampaikan bahwa sebuah pernikahan yang berakhir dengan perceraian tidak hanya berdampak bagi orang dewasa saja, tetapi juga menyebabkan trauma bagi anak. Terutama perpisahan yang terjadi saat anak masih berada di bawah umur.

Latar pada novel Assalamualaikum Calon Imam karya Madani ini terbagi menjadi tiga, yaitu latar tempat, latar waktu, dan latar sosial. Latar tempat dalam novel Assalamualaikum Calon Imam karya Madani (2018) adalah Fakultas Kedokteran, kampus, rumah sakit, rumah Ummi Nafisya, Rumah Alif, Masjid, dan lain-lain. Latar waktu adalah pada siang hari dan malam hari. Sedangkan latar sosial yang terdapat dalam novel ini adalah kehidupan kampus dan dunia kesehatan. Juga dalam novel ini menggunakan gaya bahasa atau majas seperti hiperbola, personifikasi, metafora dan lain sebagainya.

Dalam penelitian ini, peneliti menggunakan analisis wacana model Teun Van Dijk. Analisis wacana Teun Van Dijk adalah teori analisis yang menghubungkan elemenelemen wacana yang praktis dan sangat mudah dipahami. Teun Van Dijk memiliki tiga dimensi analisis data, yaitu : teks, kognisi sosial, dan konteks sosial.

Berdasarkan rumusan masalah yang telah dikemukakan peneliti telah terjawab dengan menggunakan analisis wacana model Teun Van Dijk. Isi novel banyak sekali mengandung pesan moral berdasarkan struktur teks Van Dijk dan juga pesan yang menunjukkan dampak perceraian terhadap anak. 


\section{Kesimpulan}

Berdasarkan hasil penelitian dan pembahasan terhadap novel Assalamualaikum Calon Imam karya Madani (2018) sebagaimana telah disajikan dalam bab IV, dapat disimpulkan sesuai dengan rumusan masalah. Penelitian ini berkaitan dengan pesan moral dan dampak perceraian terhadap anak yang dianalisis menggunakan analisis wacana model Teun Van Dijk. Berdasarkan teks, kognisi sosial, dan konteks sosial maka peneliti mendapat hasil penelitian dalam bentuk kalimat yang disajikan 


\section{Daftar Pustaka}

Ali Alhabsyi. A. 2015. Analisis Wacana Pesan Moral Dalam Novel Sepatu Dahlan Karya Khrisna Pabhicara. Jurnal Ilmu Komunikasi. Volume 3 Nomor 1, 2015: $101-116$.

Badara, Aris. 2014. Analisis Wacana: Teori, Metode, dan Penerapannya pada Wacana Media. Prenada Media.

Dambudjai, Robin J. 2018. Analisis Tema Dan Amanat Dalam Novel "Jangan Pergi, Lara" Oleh Mira Widjaja. Manado. Jurnal. Vol 1, No 1.

Eriyanto. 2007. Analisis Framing. Yogyakarta: LKiS.

Eriyanto. 2017. Analisis Wacana Pengantar Analisis Teks Media. Yogyakarta: LKIS.

Ghafur, Abd. 2016. Critical discourse analysis sebuah model analisis sosial kritis dalam teks media. Jurnal Okara. Vol. II, Tahun X.

Hayon, Josep. 2007. Membaca dan Menulis Wacana. Jakarta: PT Grasindo.

Hikmatunnisa. 2010. Analisis Wacana Pesan Teologi dalam Novel Musafir Cinta. Jakarta : UIN Syarif Hidayatullah. Skripsi.

Iskandar, Dudi Sabil dan Rini lestari. 2016. Mitos Jurnalisme. Yogyakarta: CV. Andi Offset.

Kriyantono, Rachmat. 2014. Teknik Praktis Riset Komunikasi. Jakarta: Kencana Prenada Media Group

Liza, Zahra Nurul dan Mohd. Harun. 2018. Analisis Pesan Moral Berdasarkan Stratifikasi Sosial Tokoh Dalam Novel-Novel Karya Arafat Nur.Jurnal Master Bahasa. Vol. 6 No. 1.

Madani. 2018. Assalamualaikum Calon Imam. Jawa Barat: Coconut Book.

Makinuddin dan Tri Hasdiyanto Sasongko. 2006. Analisis Sosial: bersaksi dalam advokad irigasi. Bandung: Yayasan Akatiga.

Matondang, Armansyah. 2014. Faktor-faktor yang Mengakibatkan Perceraian dalam Perkawinan. Jurnal Ilmu Pemerintahan dan Sosial Politik. 2 (2): 141-150.

Moleong, Lexy. J. 2011. Metode Penelitian Kualitatif. Bandung: Remaja Rosda Karya.

Mulyana, Deddy. 2005. Ilmu Komunikasi Suatu Pengantar. Bandung: Remaja Rosdakarya.

Nurgiyantoro, Burhan. 2015. Teori Pengkajian fiksi. Yogyakarta: Gajah Mada University Press.

Ramadhani, Putri Erika \& Hetty Krisnani. 2019.Analisis Dampak Perceraian Orang Tua Terhadap Anak Remaja.. Jurnal Pekerjaan Sosial. Vol.2 No: 1

Ramadhani, Zea Ayu Rizky. 2014. Tingkat Apresiasi Novel Terjemahan Dan Novel Asli Indonesia Pada Siswa Kelas VIII Mts Negeri Bantul Kota. Universitas Negeri Yogyakarta. Skripsi. 
Siregar, Ramadhan Syahmedi. 2016. Keabsahan Perceraian Perspektif Fiqh Dan Undang-Undang No. 1 Tahun 1974. Jurnal Fitrah. Vol.01 No. 1. 174

Sobur, Alex. 2012. Analisis Teks Media: Suatu Pengantar Untuk Analisis Wacana, Analisis Semiotik, dan Analisis Framing. Bandung: Remaja Rosdakarya.

Subekti, Muhamad Bagus. 2018. Analisis Wacana Pesan Moral Dalam Novel Rindu Karya Tere Liye (Model Teun A Van Dijk). Surabaya: Universitas Islam Negeri Sunan Ampel. Skripsi.

Sugiyono. 2014. Metode Penelitian Kuantitatif Kualitatif dan RND. Bandung : ALFABETA.

Warsiman. 2013. Membangun Pemahaman Terhadap Karya Sastra Berbentuk Fiksi (Telaah Sifat dan Ragam Fiksi Naratif).Surabaya. Jurnal Thaq Ãfiyy ÃT. Volume 14, No. 1. 